\title{
RBP16 is a multifunctional gene regulatory protein involved in editing and stabilization of specific mitochondrial mRNAs in Trypanosoma brucei
}

\author{
MICHEL PELLETIER and LAURIE K. READ \\ Department of Microbiology and Witebsky Center for Microbial Pathogenesis and Immunology, State University of New York-Buffalo School \\ of Medicine, Buffalo, New York 14214, USA
}

\begin{abstract}
RBP16 is a Trypanosoma brucei mitochondrial RNA-binding protein that associates with guide RNAs (gRNAs), mRNAs, and ribosomal RNAs. Based on its inclusion in the multifunctional Y-box protein family and its ability to bind multiple RNA classes, we hypothesized that RBP16 plays a role in diverse aspects of mitochondrial gene regulation. To gain insight into RBP16 function, we generated cells expressing less than $10 \%$ of wild-type RBP16 levels by tetracycline-regulated RNA interference (RNAi). Poisoned primer extension analyses revealed that edited, but not unedited, $\mathrm{CYb} \mathrm{mRNA}$ is reduced by $\sim 98 \%$ in tetracycline-induced RBP16 RNAi cells, suggesting that RBP16 is critical for CYb RNA editing. The down-regulation of CYb editing in RBP16 RNAi transfectants apparently entails a defect in gRNA utilization, as gCYb[560] abundance is similar in uninduced and induced cells. We observed a surprising degree of specificity regarding the ability of RBP16 to modulate editing, as editing of mRNAs other than CYb is not significantly affected upon RBP16 disruption. However, the abundance of the never edited mitochondrial RNAs COI and ND4 is reduced by $70 \%-80 \%$ in RBP16 RNAi transfectants, indicating an additional role for RBP16 in the stabilization of these mRNAs. Analysis of RNAs bound to RBP16 immunoprecipitated from wild-type cells reveals that RBP16 is associated with multiple gRNA sequence classes in vivo, including those whose abundance and usage appear unaffected by RBP16 disruption. Overall, our results indicate that RBP16 is an accessory factor that regulates the editing and stability of specific populations of mitochondrial mRNAs.
\end{abstract}

Keywords: RNA editing; RNA stability; Y-box protein; mitochondrial gene expression

\section{INTRODUCTION}

Kinetoplastid organisms possess an unusual mitochondrial genome composed of two types of circular DNA molecules, maxicircles and minicircles, catenated into a large network (Shapiro and Englund 1995). In the parasitic kinetoplastid, Trypanosoma brucei, it has been shown that both maxicircle and minicircle genes are transcribed polycistronically (Feagin et al. 1985; Michellotti et al. 1992; Read et al. 1992; Koslowsky and Yahampath 1997; Grams et al. 2000). Despite the polycistronic mode of transcription, however, the abundance of mature monocistronic mRNAs often varies dramatically between the mammalian bloodstream and insect (procyclic) life cycle stages of the parasite. Thus, posttranscriptional RNA processing events play a crucial role in gene regulation in trypanosome mitochondria. There are

Reprint requests to: Laurie K. Read, Department of Microbiology, SUNY Buffalo School of Medicine, 138 Farber Hall, Buffalo, NY 14214, USA; e-mail: 1read@acsu.buffalo.edu.

Article and publication are at http://www.rnajournal.org/cgi/doi/ 10.1261/rna.2160803. several points at which this regulation may be effected. For example, cleavage of polycistronic RNA precursors can regulate mature mRNA levels because, in many cases, overlapping gene organization precludes the production of both monocistronic mRNAs from a single dicistronic precursor (Read et al. 1992; Koslowsky and Yahampath 1997). mRNAs are modified by the addition of $3^{\prime}$ poly(A) tails, which are often present in two separate populations of $\sim 20$ and $\sim 200$ nt (Bhat et al. 1992). Although the precise functions of the different length poly(A) tails is not known, their relative ratios for a given mRNA often vary in a life cycle stage-dependent manner, suggesting a role in developmental gene control (Bhat et al. 1992; Read et al. 1994). RNA editing, which involves the precise insertion and deletion of uridine residues into RNAs, is absolutely required to create translatable open reading frames in the majority of mitochondrial mRNAs (for review, see Estévez and Simpson 1999; Madison-Antenucci et al. 2002; Stuart and Panigrahi 2002). Because the levels of many edited RNAs differ dramatically in different life cycle stages (for review, see Seiwert 1995), it appears that editing is also developmentally modulated. Finally, regulation of RNA stability is likely to feature 
prominently in the control of mitochondrial gene expression. For example, the differential accumulation of rRNAs (Michelotti et al. 1992) and never edited mRNAs (mRNAs that do not require RNA editing for maturation; Bhat et al. 1992) in procyclic versus bloodstream life cycle stages can only be explained by differential RNA stability. Although it is clear that multiple RNA processing events are critical in the control of gene expression in trypanosome mitochondria, the mechanisms by which any of these processes are regulated remain largely unknown.

One potential gene regulatory factor in T. brucei mitochondria is the RNA-binding protein RBP16. RBP16 was initially identified as a mitochondrial protein capable of binding the guide RNAs (gRNAs) that specify uridine insertion and deletion during RNA editing (Hayman and Read 1999). In vitro, RBP16 binds to different gRNA sequence classes primarily through their nonencoded oligo(U) tails (Hayman and Read 1999; Pelletier et al. 2000). Subsequent immunoprecipitation experiments showed that RBP16 is associated with approximately $30 \%$ of total mitochondrial gRNAs in vivo (Hayman and Read 1999), and that it can be cross-linked to metabolically labeled oligo(U) tails in intact mitochondria (Militello et al. 2000). The in vitro and in vivo association of RBP16 with gRNAs strongly suggests a role for this protein in RNA editing. A purified complex, the editosome, that consists of between 7 and 20 major proteins depending on the purification procedure (Rusché et al. 1997; Madison-Antenucci et al. 1998; Panigrani et al. 2001), can catalyze one round of RNA editing in vitro. RBP16 is apparently not a stable component of even the most complex editosome preparations (Stuart et al. 2002). Thus, RBP16 is not required for RNA editing, and any role it may play in the RNA editing process is likely to be regulatory. In addition to its gRNA binding capacity, we subsequently demonstrated that RBP16 is associated with rRNAs in vivo and can bind mRNA in vitro with a similar affinity as gRNAs (Hayman and Read 1999; Pelletier et al. 2000). These results suggest additional potential regulatory functions for RBP16.

RBP16 is a member of the conserved Y-box protein family, as defined by the presence of the evolutionarily conserved cold shock domain (Hayman and Read 1999). Y-box proteins comprise a family of DNA- and RNA-binding proteins that are involved in numerous and diverse biological processes (for review, see Graumann and Marahiel 1998). Members of this family have been shown to regulate gene expression at transcriptional (Mertens et al. 1997; Norman et al. 2001; Safak et al. 2002), posttranscriptional (Grosset et al. 2000; Evdokimova et al. 2001; Stickeler et al. 2001), and translational levels (Sommerville and Ladomery 1996; Evdokimova et al. 1998; Pisarev et al. 2002). In some cases, Y-box proteins have been reported to act through the promotion of DNA and RNA annealing (Skabkin et al. 2001) or by acting as RNA chaperones to destabilize secondary structures (Jiang et al. 1997; Bae et al. 2000). Interestingly, a single member of the Y-box family can regulate multiple processes. For example, the best-studied Y-box protein, YB-1 (p50), modulates transcription (Mertens et al. 1997; Norman et al. 2001; Safak et al. 2002), pre-mRNA splicing (Stickeler et al. 2001), mRNA stability (Chen et al. 2000; Evdokimova et al. 2001), and translation (Sommerville and Ladomery 1996, Evdokimova et al. 1998; Pisarev et al. 2002). Furthermore, YB-1 acts as a gene-specific transcriptional transactivator or repressor (Matsumoto and Wollfe 1998), and can even have opposite effects on the same promoter depending on cell type (Mertens et al. 1997). Translation is also regulated either positively or negatively by YB-1, depending on its concentration in vitro or in vivo. For instance, when the ratio of YB-1 to mRNA is low, a characteristic of polysomal mRNPs, YB-1 stimulates protein synthesis. Conversely, at increasing YB-1 to mRNA ratios, the protein gradually inhibits and eventually abolishes translation (Evdokimova et al. 1998; Pisarev et al. 2002).

Based on inclusion of RBP16 in the multifunctional Ybox protein family and its ability to bind multiple mitochondrial RNA classes, we hypothesized that RBP16 has diverse functions in the regulation of mitochondrial gene expression in T. brucei (Hayman and Read 1999). In this article, we disrupted RBP16 expression using RNA interference (RNAi) to address the role of this protein in vivo. We demonstrate that RBP16 is essential for growth of procyclic stage T. brucei. Analysis of RNA editing in cells disrupted for RBP16 revealed a specificity that was surprising in light of the broad gRNA binding properties of the protein. We observed a specific and dramatic decrease in the accumulation of edited apocytochrome $\mathrm{b}(\mathrm{CYb}) \mathrm{RNA}$ that precisely paralleled RBP16 levels, and a corresponding increase in unedited CYb mRNA. Down-regulation of CYb RNA editing was not a consequence of specific gRNA depletion. Further, analysis of RBP16-associated RNAs in wild-type $T$. brucei showed that multiple gRNA sequence classes are bound to RBP16 in vivo, and thus, the restricted effect of the protein on RNA editing is also not a consequence of binding to a specific subset of gRNAs. Together, these results suggest that the down-regulation of CYb RNA editing in RBP16 RNAi cells results from a defect in gRNA utilization. In addition to its role in RNA editing, RBP16 also functions in the regulation of mRNA stability, as demonstrated by the significant decrease in the abundance of two never edited mRNAs in RBP16 RNAi cells. Overall, our results indicate that RBP16 is an accessory factor involved in regulating multiple mitochondrial gene regulatory processes in T. brucei.

\section{RESULTS}

\section{RBP16 is essential for growth in $T$. brucei procyclic forms}

To assess the functions of RBP16, we first generated stable T. brucei cultures in which RBP16 expression was down- 
regulated by RNAi (Wang et al. 2000). A 345-bp fragment of the RBP16 coding region corresponding to nt 77-422 from the start codon was cloned into pZJM between opposing tetracycline-regulated T7 promoters. The linearized vector was transfected into T. brucei strain 29-13, which harbors integrated genes encoding T7 RNA polymerase and tetracycline repressor protein (Wirtz et al. 1999). Cells in which the RBP16 RNAi plasmid had integrated into the nontranscribed rDNA spacer were selected by addition of phleomycin to the growth medium. Several phleomycinresistant cultures were obtained, of which one was further characterized in detail. Western blot analysis showed that induction of RBP16 RNAi resulted in a decrease in RBP16 protein levels to $6 \%-10 \%$ of the levels in uninduced cells on days $4-8$ following addition of tetracycline $(1 \mu \mathrm{g} / \mathrm{mL})$ to the medium (Fig. 1A). The level of a control protein, PABPI (Hotchkiss et al. 1999), did not change following tetracycline induction, indicating that the RNAi event was specific to RBP16 (Fig. 1A). After $10 \mathrm{~d}$ of tetracycline induction, RBP16 protein returned to almost its preinduction level. Escape from RNAi has been previously observed in T. bru$c e i$, although the mechanism is unknown (Drozdz et al. 2002). Next, we evaluated the effect of RBP16 disruption on cell growth. Although tetracycline-induced cells grew normally for the first two days, growth gradually slowed, and the cells eventually stopped growing $4 \mathrm{~d}$ after induction (Fig. 1B). Uninduced cells grew similarly to the parental strain, and the decreased growth rate observed upon tetra-

$\mathbf{A}$

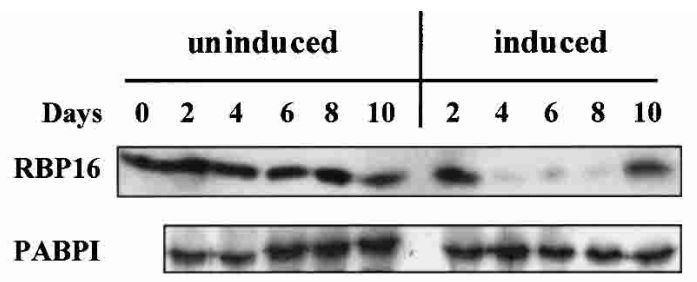

B

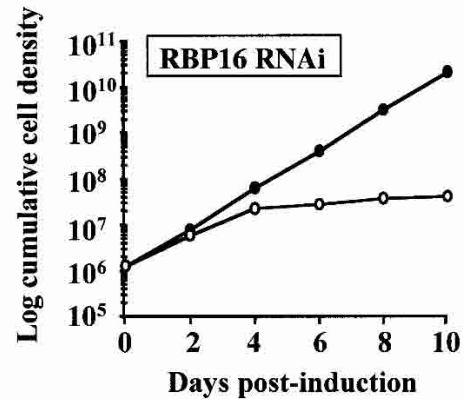

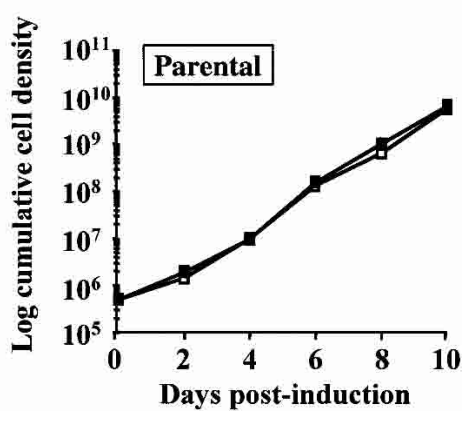

FIGURE 1. RBP16 is essential for T. brucei procyclic form cell growth. (A) Western blot analysis of total cell protein from RBP16 RNAi transfectants uninduced or induced with tetracycline for the number of days indicated. Protein from $5 \times 10^{5}$ cells was separated by $15 \%$ SDS-PAGE, transferred to nitrocellulose, and probed with anti-RBP16 or anti-PABPI antibodies. (B) Growth of procyclic form T. brucei RBP16 RNAi cells (circles) and 29-13 parental cells (squares), either uninduced (closed symbols) or induced with tetracycline (open symbols). Growth curves were obtained by plotting the cell densities as the product of the cell density and the total dilution. cycline induction was specific to cells harboring the RBP16 RNAi construct, as tetracycline addition had no effect on growth of the parental strain (Fig. 1B). Consistent with the increase in RBP16 protein on day 10 , the cell growth rate returned to normal after $12 \mathrm{~d}$ (data not shown). A similar growth defect was observed in two additional RBP16 RNAi cultures that were examined after tetracycline induction. Together, these experiments indicate that RBP16 is an essential protein for the growth of procyclic form T. brucei.

\section{Effect of RBP16 disruption on RNA editing}

Previous experiments showed that RBP16 binds different gRNA sequence classes in vitro (Hayman and Read 1999) and is associated with a substantial fraction of the mitochondrial gRNA population in vivo (Hayman and Read 1999; Militello et al. 2000; see also Fig. 7A below). The association of RBP16 with gRNAs strongly suggests that this protein plays a role in the regulation of RNA editing. To assess the effect of RBP16 disruption on RNA editing, we performed a poisoned primer extension assay that allowed us to quantify unedited and edited versions of the same mRNA simultaneously (Missel et al. 1997). Steady-state RA isolated from uninduced cells and cells whose RBP16 pression had been disrupted by tetracycline induction compared over multiple days postinduction. We inialyzed apocytochrome $b(\mathrm{CYb}) \mathrm{RNA}$, which is exclusively edited in procyclic form trypanosomes (Feagin et al. 1987). As shown in Figure 2A, the abundance of edited CYb RNA is dramatically decreased in tetracycline-induced cells compared to uninduced cells. Quantification of the percent of CYb RNA that was edited in induced versus uninduced cells revealed a $92 \%-98 \%$ decrease in the percent edited RNA on days 4-8 following tetracycline induction (Fig. 2B). A similar decrease in edited $\mathrm{CYb}$ RNA levels was also observed when analyzed by PCR using primers flanking the edited region (data not shown). Strikingly, the abundance of edited $\mathrm{CYb}$ mRNA precisely paralleled that of RBP16 protein levels (cf. Figs. 2 and 1A), decreasing on day 4 and increasing again on day 10 postinduction. This indicates that the effect on the abundance of edited $\mathrm{CYb}$ transcripts can be specifically attributed to RBP16 disruption. Coincident with the decrease in edited CYb mRNA, the amount of unedited CYb RNA in induced RBP16 RNAi cells increased between 22 and $37 \%$ on days 4 to 8 postinduction (Fig. 2A). Because an average of $28 \%$ of the total CYb RNA population 
A

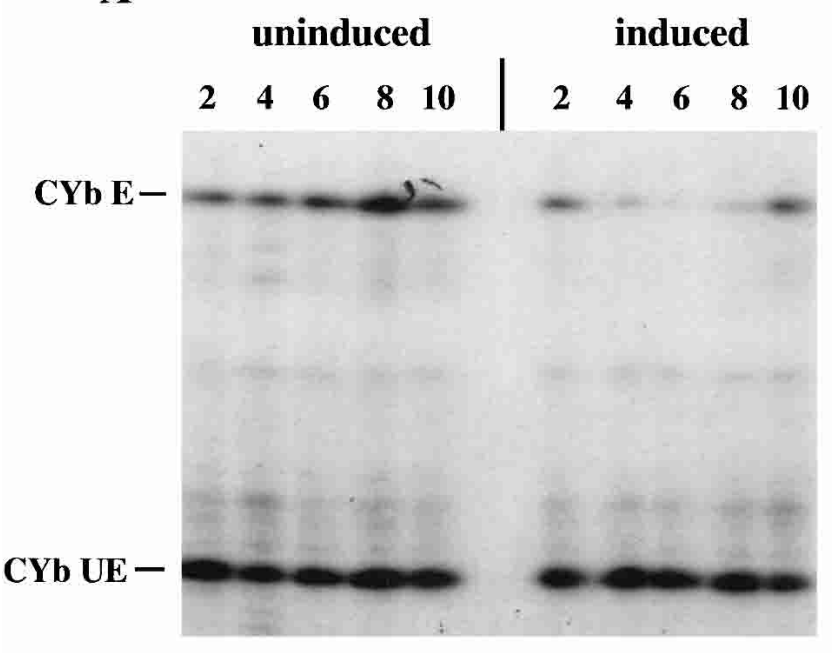

B

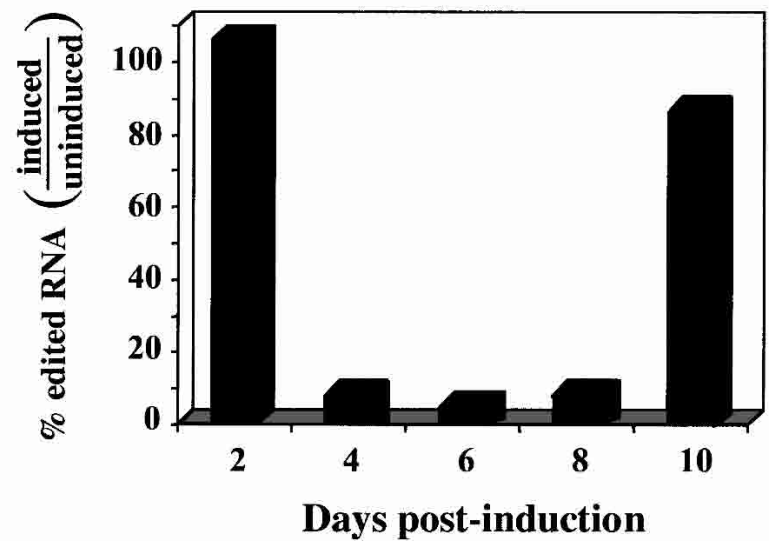

FIGURE 2. Decrease in the abundance of edited CYb mRNA upon RBP16 disruption in T. brucei procyclic forms. (A) Poisoned primer extension analysis of $\mathrm{CYb}$ unedited (CYb UE) and edited (CYb E) mRNA levels. Primer extensions were performed using $10 \mu \mathrm{g}$ total RNA isolated from cells grown in the absence (uninduced) or presence (induced) of tetracycline for up to $10 \mathrm{~d}$. (B) Quantification of the percent edited CYb (represented as the amount of edited $\mathrm{CYb} /$ total CYb in tet-induced cells vs. uninduced cells) over a period of $10 \mathrm{~d}$ postinduction.

was edited in uninduced cells during this same time period, it appears that unedited CYb RNA accumulated in tetracycline-induced RNAi cells approximately in proportion to the reduction in edited CYb RNA. The corresponding decreases in edited $\mathrm{CYb}$ RNA and increases in unedited $\mathrm{CYb}$ RNA in cells depleted for RBP16 strongly suggest that RBP16 plays a critical role in CYb RNA editing. We cannot rule out, however, that RBP16 is additionally involved in specifically modulating the stability of edited CYb mRNA.

We next examined the degree of editing of additional mitochondrial RNAs to determine the range of RBP16 function. We used poisoned primer extension to determine the levels of unedited and edited cytochrome oxidase II (COII) RNA, which, like CYb, is solely edited in the procyclic stage. We also analyzed RNAs that are constitutively edited in both life cycle stages: ATPase subunit 6 (A6), cytochrome oxidase III (COIII), mitochondrial unidentified reading frame 2 (MURF2), and the $5^{\prime}$ domain of $\mathrm{NADH}$ dehydrogenase subunit 7 (ND7). Editing of the ribosomal protein S12 (RPS12) mRNA, which is preferentially edited in the bloodstream form, was also analyzed by poisoned primer extension. Although slight decreases in the levels of some edited RNAs were observed upon tetracycline induction, in no case were the effects as significant as those observed for $\mathrm{CYb}$, nor did decreases in edited RNA abundance generally parallel RBP16 protein levels (Fig. 3 and data not shown).

Because poisoned primer extension only permits analysis of editing at a limited number of sites downstream from the primer (upstream relative to the mRNA), we utilized PCR to examine whether the effects of RBP16 disruption might be reflected in the overall extent of editing of a given RNA. That is, does RBP16 disruption affect the processivity of editing along an RNA? Primers that anneal to the $5^{\prime}$ and $3^{\prime}$ never edited regions of either COIII or RPS12 mRNAs were used to amplify unedited, partially edited, and fully edited RNAs from uninduced and induced cells (Schnaufer et al. 2001). The products were analyzed by agarose gel electrophoresis and EtBr staining. Neither the fraction of each of these RNAs that is edited nor the extent of editing within the RNA population changed significantly upon RBP16 disruption (data not shown). Thus, we conclude that RBP16 acts in a specific fashion to modulate the levels of edited CYb mRNA.

The unexpected specificity of RBP16 prompted us to ask whether the action of RBP16 disruption on edited CYb RNA levels was a consequence of altered CYb gRNA abundance. Toward this aim, we carried out RT-PCR quantification of gCYb [560], the gRNA that initiates the editing of CYb (Riley et al. 1995). Semi-quantitative RT-PCR analysis showed that $\mathrm{gCYb}[560]$ is present at comparable levels in uninduced cells and tetracycline-induced cells (Fig. 4A). Thus, RBP16 does not function by modulating steady-state levels of $\mathrm{gCYb}[560]$, and the reduced abundance of edited $\mathrm{CYb}$ mRNA is not a consequence of reduced gRNA levels. Quantification of another gRNA, gA6[14], also revealed that the abundance of this gRNA was not altered upon RBP16 disruption (Fig. 4B). These data demonstrate that RBP16 does not play a role in the regulation of gRNA stability, and suggest a more likely role in regulation of gRNA utilization.

\section{Role of RBP16 in RNA stability}

To address whether RBP16 regulates the stability of mitochondrial RNAs, we next determined whether RBP16 dis- 
A

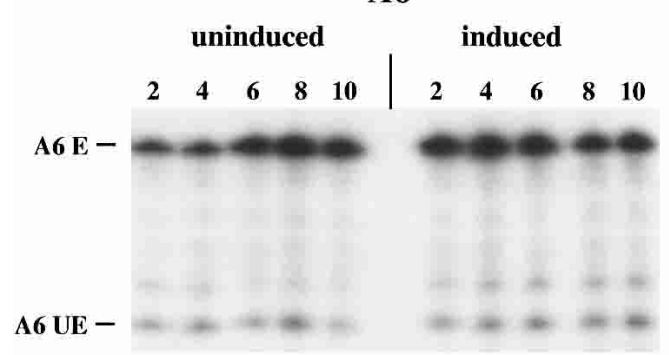

B

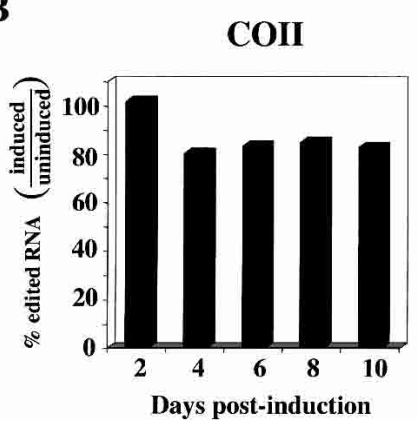

C

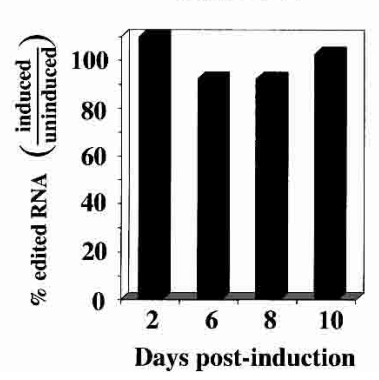

FIGURE 3. Poisoned primer extension analysis of A6 (A), COII (B), and MURF2 $(C)$ RNA editing in RBP16 RNAi cells. Primer extensions were performed using 5-10 $\mu \mathrm{g}$ total RNA isolated from cells grown in the absence (uninduced) or presence (induced) of tetracycline for $10 \mathrm{~d}$. The percent edited RNA (represented as the amount of edited RNA/total RNA in tetracycline-induced cells vs. uninduced cells) is shown over a period of $10 \mathrm{~d}$ postinduction.

abundance of edited CYb mRNA, as well as that of the never edited COI and ND4 mRNAs. As mentioned above, the $\mathrm{CYb}$ transcript is exclusively edited in procyclic form parasites (Feagin et al. 1987). In addition, COI mRNA is more abundant in procyclic form than bloodstream form trypanosomes (Jasmer et al. 1985). These results suggest that RBP16 might be upregulated in procyclic form $T$. brucei. To determine whether RBP16 expression is developmentally regulated during the trypanosome life cycle, we performed Western blot analyses of total procyclic and bloodstream form parasite extracts. As shown in Figure 6, RBP16 protein levels are similar in the two life cycle stages, indicating that RBP16 is constitutively expressed throughout the T. brucei life cycle. Thus, if RBP16 participates in the developmental regulation of specific mRNA levels, its effect is not merely a consequence of its concentration, but may be attributed to RBP16-associated regulatory proteins (Hayman et al. 2001) and/or posttranslational modifications of RBP16 (Pelletier et al. 2001). ruption altered the levels of mitochondrially encoded RNAs that do not require RNA editing for maturation (never edited RNAs). We analyzed the levels of cytochrome oxidase I (COI) and NADH dehydrogenase subunit 4 (ND4) mRNAs by poisoned primer extension in RBP16 RNAi transfectants either uninduced or induced with tetracycline. Both COI and ND4 mRNA levels were altered with a profile that approximated the levels of RBP16 protein (cf. Figs. 5 and 1A). COI mRNA was reduced in induced versus uninduced cells by greater than $40 \%$ on day 4 postinduction, and was maximally reduced by $65 \%$ on day 8 . Importantly, COI mRNA levels greatly increased on day 10, paralleling RBP16 protein levels. Likewise, ND4 mRNA was reduced by approximately $80 \%$ following tetracycline induction, but increased again at day 10. Comparison of Figure 5 with Figure $3 \mathrm{~A}$ demonstrates that the down-regulation of COI and ND4 mRNAs on days 4-8 postinduction is a consequence of RBP16 depletion, and not due to differences in RNA recovery between these samples. Thus, RBP16 affects the abundance of never edited RNAs, thereby indicating an additional role for the protein, namely in the regulation of mitochondrial mRNA stability.

\section{RBP16 is constitutively expressed}

The results of the poisoned primer extension analyses clearly indicated that RBP16 acts in a specific fashion to regulate the

\section{RBP16 is associated with multiple gRNAs in vivo}

We next asked whether the specific effect of RBP16 disruption on the CYb RNA editing is due to preferential binding of $\mathrm{CYb}$ gRNAs. To identify gRNAs that are associated with RBP16 in vivo, we immunoprecipitated RBP16 from wildtype procyclic form mitochondria. Guanylyl transferase labeling of total gRNAs in bound and unbound fractions confirmed that RBP16 is associated with approximately $30 \%$ of total mitochondrial gRNAs as previously reported (Hayman and Read 1999; Fig. 7A). We tested for the presence of specific gRNAs in the bound and unbound fractions by Northern blot analysis. We found that $13.8 \%$ of total of $\mathrm{gCYb}[558]$ is RBP16-associated after correction for the signal obtained with preimmune serum (Fig. 7B). However, $\mathrm{gCYb}[558]$ was not specifically bound to RBP16; a similar fraction of gCR6[100] was also RBP16-associated (Fig. 7B). Thus, RBP16 binds in vivo to gRNAs specifying editing of RNAs that are both affected and unaffected by RBP16 disruption. This is not entirely unexpected, as the primary binding determinant for RBP16 binding is the oligo(U) tail that is present on all gRNAs (Hayman and Read 1999; Pelletier et al. 2000). These results indicate that RBP16 does not manifest its specific regulation of edited $\mathrm{CYb}$ mRNA abundance by virtue of binding a restricted subset of gRNAs. Because less than $30 \%$ of each of the gRNAs examined here were RBP16-associated, these results additionally 


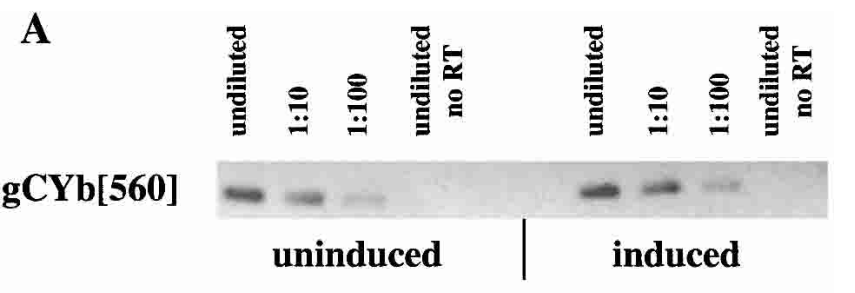

B

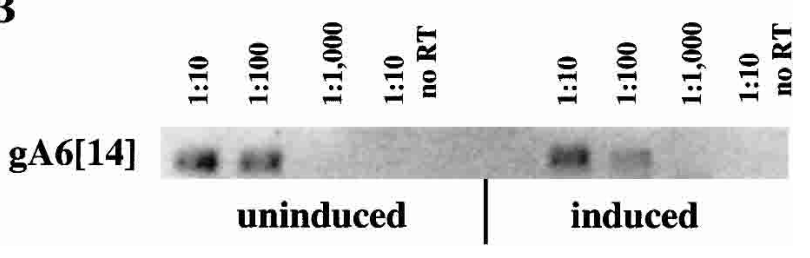

FIGURE 4. Quantification of gCYb[560] (A) and gA6[14] (B) gRNAs by RT-PCR in RBP16 RNAi cells. RNA isolated from cells grown in the absence (uninduced) or presence (induced) of tetracycline for $6 \mathrm{~d}$ was used to synthesize cDNA using primers complementary to the encoded $3^{\prime}$ region of the gRNA. cDNA was diluted as indicated and the abundance of gRNAs was determined by RT-PCR using gRNA-specific primers.

suggest that gRNAs other than those analyzed here are either more abundant or have a greater percentage of their total population bound to RBP16.

\section{DISCUSSION}

In this report, we demonstrate that the mitochondrial RNA binding protein RBP16 is essential for growth in procyclic form T. brucei. Tetracycline-induced RBP16 RNAi resulted in a dramatic reduction in RBP16 protein expression, which was accompanied by a cessation of growth. RBP16 disruption also lead to a massive down-regulation of edited $\mathrm{CYb}$ mRNA, as well as substantial decreases in the levels of the never edited mRNAs, COI and ND4. After $10 \mathrm{~d}$ of tetracycline induction, RBP16 protein returned to almost preinduction levels as did the abundance of edited CYb, COI, and ND4 RNAs, providing further evidence that RBP16 functions to regulate the levels of these specific RNAs. Following the reestablishment of the complete procyclic form mitochondrial RNA population, cell growth returned to normal. These results demonstrate that RBP16 plays a critical role in regulating the expression of a subset of mitochondrial genes in T. brucei, and that accurate expression of these genes is required for cell growth.

RBP16 disruption leads to a very dramatic decrease in the accumulation of edited $\mathrm{CYb}$ mRNA. The corresponding increase in unedited CYb RNA strongly suggests that editing of CYb RNA is compromised when RBP16 levels are reduced. Because $\mathrm{gCYb}[560]$, the gRNA that initiates editing of CYb RNA, is present at comparable levels in uninduced cells and tetracycline-induced cells, we conclude that the down-regulation of CYb mRNA editing observed in RBP16 RNAi cells is likely a result of reduced gRNA utilization. Although the biochemical mechanism of RBP16 action is unknown, we can envision scenarios by which RBP16 could regulate the utilization of gRNAs during editing based on the reported functions of some Y-box proteins and the known properties of gRNAs and gRNA-mRNA interactions during editing. For example, some bacterial Y-box proteins function as RNA chaperones, destabilizing RNA secondary structures at low temperature, and thereby facilitating translation and antitermination (Jiang et al. 1997; Bae et al. 2000). In a similar fashion, RBP16 may unfold the characteristic two stem-loop gRNA secondary structure (Schmid et al. 1995), thus permitting a favorable interaction with pre-mRNA, other gRNA-binding proteins, or proteins of the editosome. The mammalian $\mathrm{YB}-1$ protein has been shown to promote RNA-RNA annealing, suggesting that RBP16 could also function in this capacity. Müller et al. (2001) demonstrated that the gRNA-binding protein gBP21 facilitates annealing between the $5^{\prime}$ anchor portion of gRNAs and the region downstream of the editing site in mRNAs. It is conceivable that RBP16 could similarly facilitate the association between the gRNA oligo(U) tail and the mRNA region just upstream of the editing site (Leung and Koslowsky 1999). Determining whether RBP16 possesses either RNA chaperone or RNA annealing activities will be the subject of future experiments.

The effect of RBP16 disruption on edited RNA abundance was specific to $\mathrm{CYb}$; the levels of other edited RNAs were not significantly affected. This apparent specificity of RBP16 action was surprising. Because RBP16 binds multiple RNA classes with relatively low specificity (Hayman and Read 1999; Pelletier et al. 2000), a more global effect of RBP16 disruption on the levels of several RNAs might have been expected. One potential explanation for the specificity of RBP16 action is that editing of other RNAs is normally facilitated by RBP16, but that editing of $\mathrm{CYb}$ requires a greater amount of RBP16 than does editing of other mRNAs. RBP16 is a relatively abundant mitochondrial protein (Hayman and Read 1999), and so the $6 \%-10 \%$ of wildtype RBP16 levels present in RBP16 RNAi cells may still be sufficient for most RNAs, but insufficient to achieve correct editing of CYb RNA. Alternatively, whereas editing of CYb RNA may strictly depend on RBP16, other mitochondrial proteins may be able to compensate for the loss of RBP16 in regulating editing of other RNAs in the RBP16 RNAi transfectants. One candidate is the mitochondrial oligo(U)-binding protein TBRGG1, which was identified by UV crosslinking of gRNA, and has been shown to colocalize with an in vitro RNA editing activity (Vanhamme et al. 1998). Another interesting possibility is that RBP16 specificity is dictated by RBP16-gRNA ratios. In the case of the mammalian YB-1 protein, a low YB-1 to mRNA ratio, a feature of poly- 
A

$\mathbf{A}$

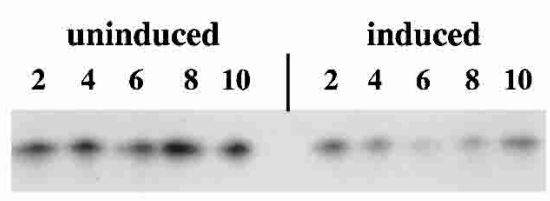

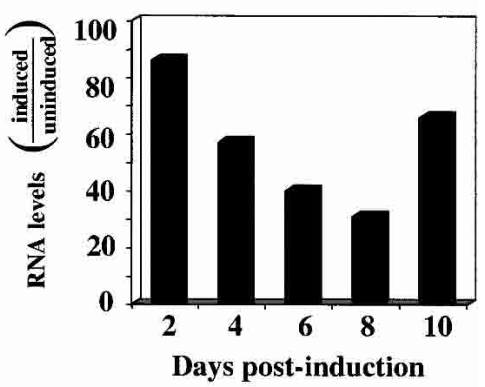

B

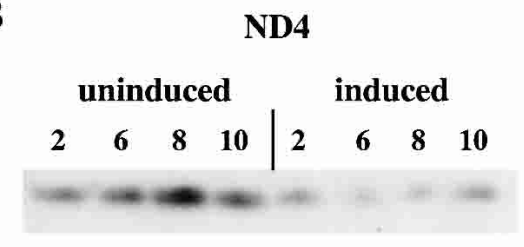

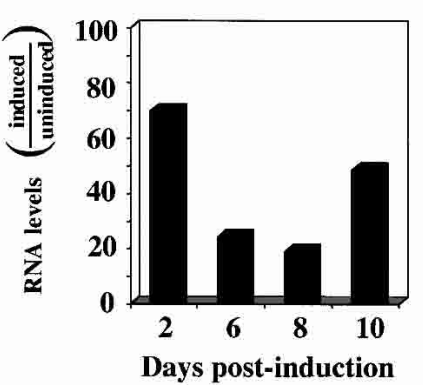

FIGURE 5. The never-edited ND4 and COI mRNAs are destabilized upon RBP16 disruption. Poisoned primer extension analysis of the abundance of COI $(A)$ and ND4 $(B)$ mRNA. Primer extensions were performed using $10 \mu \mathrm{g}$ total RNA isolated from cells grown in the absence (uninduced) or presence (induced) of tetracycline for up to $10 \mathrm{~d}$. The relative RNA levels (represented as the amount of RNA in induced/uninduced cells) is shown over a period of 10 d postinduction.

somal mRNPs, leads to a stimulation of protein synthesis. Conversely, at increasing YB-1 to mRNA ratios, the protein gradually inhibits and eventually abolishes translation (Evdokimova et al. 1998; Pisarev et al. 2002). Although the abundance of most mitochondrial mRNAs and gRNAs has not been characterized, it is feasible that regulation of editing by RBP16 is achieved by a similar mechanism. Finally, RBP16 may engage in specific protein-protein interactions. Gene-specific regulatory proteins are known to be of key importance in regulating mitochondrial gene expression in yeast. For example, the nuclearly encoded CBP1 protein is required specifically for the stability of the mitochondrial cytochrome $b$ mRNA (Weber and Dieckmann 1990). In addition, most, if not all, Saccharomyces cerevisiae mitochondrial transcripts are dependent on transcript-specific translational activator proteins (Constanzo and Fox 1990; Rödel 1997; Islas-Osuna et al. 2002). Our ongoing identification of proteins that interact with RBP16 in T. brucei mitochondria (Hayman et al. 2001) may yield gCYb-specific factors.

It is also of interest, in light of the $\mathrm{CYb}$ specificity of RBP16, that CYb is one of only two RNAs whose editing is exclusively restricted to procyclic form trypanosomes. The other procyclic-specific edited RNA is COII, the abundance of which was not altered in RBP16 RNAi cells. However, editing of COII is very unusual in that the gRNA that directs COII editing is located at the $3^{\prime}$ end of the mRNA itself and is polyadenylated rather than polyuridylated (Koslowsky and Yahampath 1997). Because RBP16-gRNA binding is mediated largely through the gRNA oligo(U) tail (Hayman and Read 1999), interaction of RBP16 with gCOII-COII is likely to be different than with the other gRNAs. Thus, in specifically facilitating CYb editing, RBP16 may be acting as a procyclic form developmental editing regulatory factor. This would be consistent with regulation of gRNA utilization by $\mathrm{RBP} 16$, as developmental regulation of specific editing events, including that of $\mathrm{CYb}$ RNA, has been proposed to take place at the level of gRNA utilization. That is, steady-state levels of specific gRNAs do not vary developmentally in accordance with the levels of mRNAs whose editing they specify, and so their interaction with the editing machinery and/or pre-mRNA must be regulated in developmental fashion (Koslowsky et al. 1992; Riley et al. 1995). Although RBP16 levels do not vary significantly between procyclic and bloodstream form T. brucei, developmental specificity could be achieved by interaction with additional proteins and/or by posttranslational modification. RBP16 is known to undergo multiple, mutually exclusive arginine methylation events in procyclic forms (Pelletier et al. 2001), and these modifications are likely to influence RBP16 protein-protein interactions (e.g., Bedford et al. 2000; Zhu et al. 2002). We are currently investigating whether the pattern of RBP16 methylation varies in a developmentally regulated manner and whether methylation affects association of RBP16 with other mitochondrial factors.

Several other proteins have recently been demonstrated, through genetic manipulation of trypanosomes, to be required for proper RNA editing. The majority of these proteins are integral components of the editosome (Stuart et al. 2002), including the Band IV or TBMP52 RNA ligase

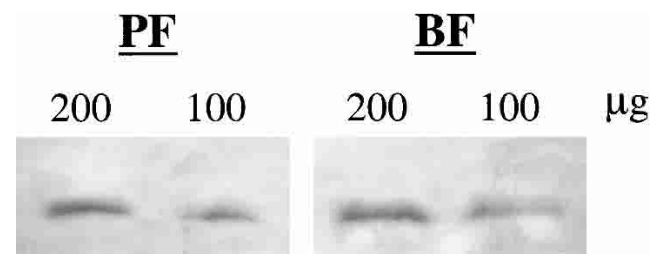

FIGURE 6. Western blot analysis of RBP16 protein levels in procyclic (PF) and bloodstream (BF) form T. brucei. Whole-cell extracts were prepared as described in Materials and Methods. Either 100 or $200 \mu \mathrm{g}$ of PF or BF cell protein was analyzed by Western blot with anti-RBP16 antibodies. 


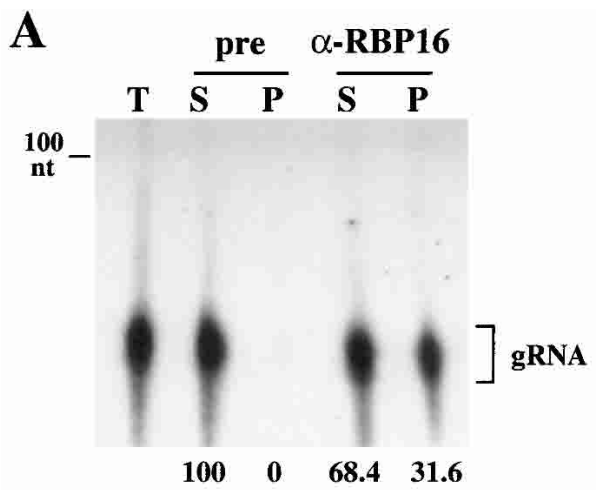

B

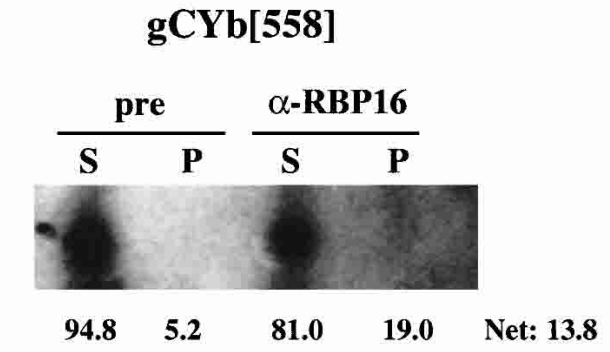

gCR6[100]

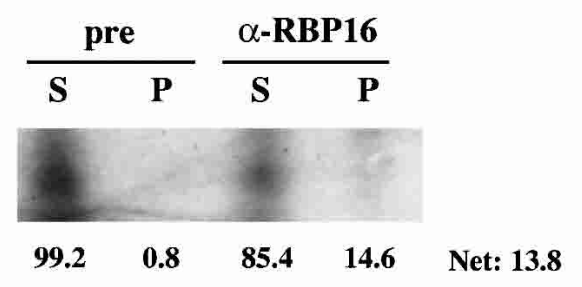

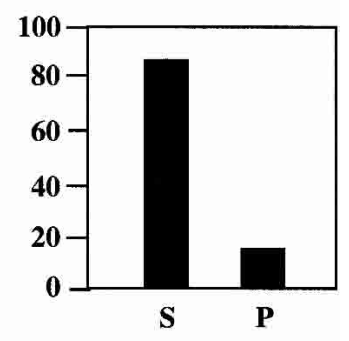

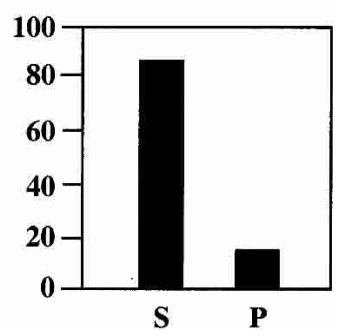

FIGURE 7. RBP16 is associated with multiple gRNAs in vivo. Mitochondrial extracts from wild-type procyclic form T. brucei were immunoprecipitated with either preimmune IgGs (pre) or anti-RBP16 antibodies ( $\alpha$-RBP16). RNA was then isolated from the supernatants $(\mathrm{S})$ and the pellets (P). (A) Labeling of total mitochondrial gRNAs. Total mitochondrial RNA ( $\mathrm{T}$; half of the starting material) and RNA isolated from preimmune or $\alpha$-RBP16 supernatants and pellets was labeled by capping with guanylyl transferase and $\left[\alpha-{ }^{32} \mathrm{P}\right] \mathrm{GTP}$. Numbers below the figure represent the percent of the total RNA present in supernatant and pellet of either preimmune or $\alpha$-RBP16 samples. (B) Supernatants and pellets obtained from immunoprecipitation were tested for the presence of specific gRNAs by Northern blot. Numbers below the figures represent the percent of the total RNA present in supernatant and pellet of either preimmune or $\alpha$-RBP16 samples. Net equals the amount of a given RNA present in the $\alpha$-RBP16 pellet minus that present in the preimmune pellet. Graphs on the right represent the percent of a given gRNA present in $\alpha$-RBP16 supernatant and pellet after correction for values obtained with preimmune serum.

(Huang et al. 2001; Schanufer et al. 2001), the mHel61p RNA helicase (Missel et al. 1997), and a protein of unknown function, TbMP81 (Drozdz et al. 2002). The mitochondrial $3^{\prime}$ terminal uridylyl transferase that was shown by Aphasizhev et al. (2002) to be required for editing in T. brucei has not been demonstrated to be an editosome component, but is thought to be a critical enzymatic constituent of the editing pathway. In addition to RBP16, other RNA-binding proteins have also been proposed to function in RNA editing in T. brucei. For example, gBP21 binds the encoded portion of gRNAs with high affinity (Köller et al. 1997) and possesses gRNAmRNA annealing activity (Müller et al. 2001). Bloodstream form T. brucei in which both gBP21 gene copies were deleted demonstrated no growth phenotype, although they were unable to differentiate into procyclic forms (Lambert et al. 1999). Editing of A6 and ND7 RNAs was not dramatically or consistently affected in bloodstream form gBP21 mutants. However, deletion of gBP21 resulted in a striking decrease in unedited and never edited RNA levels, indicating that the protein has a significant effect on RNA stability. It will be of great interest to know the degree to which RNA editing and stability are affected in T. brucei procyclic forms in which gBP21 and its homolog gBP25 (Blom et al. 2001) have been disrupted. Another candidate editing factor is the oligo(U) binding protein, TBRGG1, which cosediments on glycerol gradients with in vitro editing activity (Vanhamme et al. 1998). Finally, the REAP-1 mRNA-binding protein has been proposed to function by recruiting premRNAs to the editosome (Madison-Antenucci et al. 1998; Madison-Antenucci and Hajduk 2001). To date, there have not been any genetic studies investigating the phenotypes of TBRGG1- or REAP-1-depleted trypanosomes. Thus, the results presented here place RBP16 as an editing accessory factor, the disruption of which results in the most dramatic effect on an editing event yet reported for any trypanosome editing accessory factor.

In addition to the effect of RBP16 disruption on CYb RNA editing, analysis of the never edited RNAs COI and ND4 in RBP16 RNAi cells revealed an additional function for RBP16 in the regulation of mitochondrial mRNA stability. The Y-box protein YB-1 has been shown to stabilize the interleukin-2 (IL-2) mRNA by binding to a specific sequence within the $5^{\prime}$ UTR of the mRNA (Chen et al. 2000). It is believed that YB-1 does not protect the IL-2 mRNA by itself, but rather acts as a docking protein that recruit a cofactor whose function is to inhibit IL-2 mRNA decay. Although little is known about mitochondrial mRNA 
turnover mechanisms in trypanosomes, it is possible to imagine that RBP16 may, by interacting with certain mRNAs such as COI and ND4, prevent degradation of these mRNAs on its own, or by recruiting other proteins that then stabilize the mRNAs and prevent degradation by nucleases. This could be achieved, for example, by modulation of mRNA structure by RBP16, allowing the recruitment of other mitochondrial proteins.

Overall, the results presented here indicate that RBP16 is a multifunctional protein that influences the editing and stability of a subset of mitochondrial mRNAs. These studies reveal a surprising level of specificity regarding RBP16 action. The mechanisms by which RBP16 acquires its multifunctional character and specificity remain to be determined. Both multifunctionality and specificity presumably involve interaction with a range of protein-binding partners. RBP16 protein-protein interactions may be further regulated by methylation of particular arginine residues in the RBP16 RGG domain (Pelletier et al. 2001). Future experiments will address in detail the molecular interactions and mechanisms by which RBP16 regulates different facets of trypanosome mitochondrial gene expression.

\section{MATERIALS AND METHODS}

\section{Plasmid constructs}

To down-regulate RBP16 expression by RNAi, a 345-bp fragment of the RBP16 coding region (Hayman and Read 1999) was amplified by 30 cycles of PCR from total procyclic form cDNA using primers RBP16i-5' and RBP16i-3' (see below), which allowed introduction of XhoI and HindIII restrictions sites, respectively. The PCR product was then ligated into the XhoI and HindIII sites of pZJM (a generous gift from Dr. Paul T. Englund, Johns Hopkins School of Medicine; Wang et al. 2000).

\section{DNA oligonucleotides}

The following oligodeoxynucleotides (Integrated DNA Technologies) were used in these studies (added restriction sites are underlined). RBP16i-5' (5'-CCGCTCGAGTCTGGACGTGGTTTTGGT TTTATT-3') and RBP16i-3' (5'-CCCAAGCTTAAAGTCATCGC TGAAGCTCTGGTGC-3') were used to amplify a 345-bp fragment of the RBP16 coding region used for RNAi.

For primer extension analyses, the following oligodeoxynucleotides were employed:

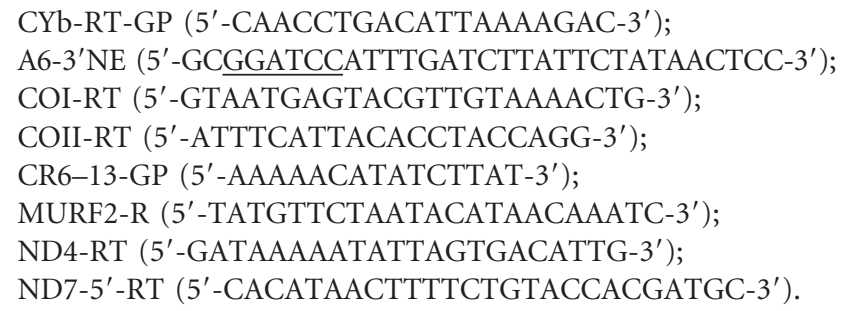

The following oligodeoxynucleotides were used to amplify specific gRNAs from uninduced and induced RBP16 RNAi cells:
gCYb $[560]-5^{\prime}$ (5'-GCGAATTCGTAAAAGACAATGTAGATT-3') and $\mathrm{gCYb}[560]-3^{\prime}$ (5'-GCGGATCCTAGAGAGTAGTTATCCTC$\left.3^{\prime}\right)$ for gCYb $[560]$; gA6[14]-5' (5'-GCGAATTCGATGTAAATA ACCTG-3') and gA6[14]-3' (5'-GCGGATCCAAAATTCACTAT ATA-3') for gA6[14]. To detect RBP16-associated gRNAs by Northern blot, the oligonucleotides gCYb[558]-3' (5'-GCGGA TCCTTATTCCCTTTATCACC) and gCR6[100]-3' (5'-GCGGA TCCTATTTACTCACTTTATCT-3') were used.

\section{Trypanosome growth, transfection, and induction of RNAi}

Procyclic form T. brucei brucei clone IsTaR1 stock EATRO 164 was grown as described (Brun and Schonenberg 1979). Bloodstream form T. brucei strain 427 (a generous gift from Dr. George A.M. Cross, Rockefeller University) was cultured in HMI-9 medium as described (Hirumi and Hirumi 1989). Procyclic T. brucei strain 29-13 (provided by Dr. George A.M. Cross, Rockefeller University), which contains integrated genes for T7 RNA polymerase and the tetracycline repressor, were grown in SDM-79 supplemented with $15 \%$ fetal bovine serum as described (Brun and Schonenberg 1979; Wirtz et al. 1999), in the presence of G418 $(15 \mu \mathrm{g} / \mathrm{mL})$ and hygromycin $(50 \mu \mathrm{g} / \mathrm{mL})$. For transfection, cells $\left(1 \times 10^{8}\right)$ were washed once in $5 \mathrm{~mL}$ ice-cold Cytomix (Van den Hoff et al. 1992) and resuspended in $0.5 \mathrm{~mL}$ of Cytomix containing $20 \mu \mathrm{g}$ of plasmid linearized with NotI. Transfections (two pulses) were carried out on ice in 2-mm cuvettes using a Bio-Rad electroporator with the following settings : $800 \mathrm{~V}, 25 \mu \mathrm{F}$, and $40 \mathrm{ohms}$. Following transfection, cells were transferred into $10 \mathrm{~mL}$ SDM-79 supplemented with G418 and hygromycin and allowed to recuperate for $20 \mathrm{~h}$. Selection was then applied by the addition of $2.5 \mu \mathrm{g} / \mathrm{mL}$ phleomycin, and the cells were grown for four weeks to obtain stable transfectants. For induction of dsRNA, cells were cultured in the presence of $1 \mu \mathrm{g} / \mathrm{mL}$ tetracycline. Growth curves were obtained by plotting the cell densities (represented as the product of the cell number and the total dilution) obtained over a period of $10 \mathrm{~d}$.

\section{Western blotting}

For analysis of RBP16 levels in uninduced and induced transfectants, protein from $5 \times 10^{5}$ cell equivalents was separated by $15 \%$ SDS-PAGE and transferred electrophoretically to a nitrocellulose membrane (Schleicher and Schuell) at $50 \mathrm{~V}$ for $35 \mathrm{~min}$ in $10 \mathrm{mM}$ 3-[Cyclohexylamino]-1-propanesulfonic acid (CAPS) buffer ( $\mathrm{pH}$ 11.0 ) containing $10 \%$ methanol. The membrane was probed using either anti-RBP16 (Hayman and Read 1999) or anti-poly(A)-binding protein (PABPI, a generous gift from Dr. Noreen Williams, State University of New York-Buffalo; Pitula et al. 2002) antibodies, at a 1:1000 and 1:2500 dilution, respectively. Primary antibodies were detected using goat anti-rabbit antibody coupled to horseradish peroxidase (Pierce Endogen), and detected by enhanced chemiluminescence (ECL; Amersham Pharmacia Biotech).

For comparison of RBP16 levels in procyclic (EATRO 164) and bloodstream form cells, parasite extracts were prepared by passage through a 26-gauge needle, and mitochondria were lysed with the addition of $0.2 \%$ Nonidet P- 40 . Total procyclic and bloodstream form proteins were precipitated with $4 \%$ TCA, resuspended in SDS sample buffer, and loaded onto a $15 \%$ SDS-PAGE gel. Proteins were transferred and the membrane was probed with antiRBP16 antibodies as described above. 


\section{Primer extension analyses}

Total RNA was purified from $2 \times 10^{8}$ to $1 \times 10^{9}$ cells (Purescript RNA Isolation Kit, Gentra Systems). Primer extensions were performed with 5-10 $\mu \mathrm{g}$ total RNA and 0.4 pmole $5^{\prime}-{ }^{32} \mathrm{P}$-labeled oligodeoxynucleotide primer. Samples were heated for $5 \mathrm{~min}$ at $95^{\circ} \mathrm{C}$, cooled on ice for $5 \mathrm{~min}$, and annealed for $60 \mathrm{~min}$ at $37^{\circ} \mathrm{C}$ in TE buffer (10 mM Tris at pH 8.0, 1 mM EDTA) containing 120 $\mathrm{mM} \mathrm{KCl}$. Extension reactions were performed in $50 \mathrm{mM}$ Tris- $\mathrm{HCl}$ (pH 8.3), $50 \mathrm{mM} \mathrm{KCl,} 10 \mathrm{mM} \mathrm{MgCl}$, $5.5 \mathrm{mM}$ DTT, $150 \mu \mathrm{M}$ each dATP, dCTP, and dTTP, $75 \mu \mathrm{M}$ ddGTP, $20 \mathrm{U}$ of RNasin (Promega), and $10 \mathrm{U}$ of AMV reverse transcriptase (Promega) for 45 min at $47^{\circ} \mathrm{C}$. RNA was removed by RNase A digestion $(2 \mu \mathrm{g})$ for $15 \mathrm{~min}$ at $37^{\circ} \mathrm{C}$ in the presence of $1 \mu \mathrm{g}$ salmon sperm DNA, and the extension products were precipitated with ethanol and separated on a $8 \mathrm{M}$ urea/10\% polyacrylamide gel. Gels were analyzed by autoradiography followed by densitometry of nonsaturated autoradiographs.

\section{Determination of gRNA abundance by RT-PCR in RBP16 RNAi cells}

The abundance of gRNAs was determined by reverse transcription-PCR amplification. Total RNA was isolated from $2 \times 10^{8}$ to $1 \times 10^{9}$ cells grown in the absence or presence of $1 \mu \mathrm{g} / \mathrm{mL}$ tetracycline for $6 \mathrm{~d}$ using the Purescript RNA Isolation Kit (Gentra Systems). Five micrograms of total RNA were the digested with 25 $\mathrm{U}$ of DNase I (Invitrogen) on ice for $60 \mathrm{~min}$. cDNA was synthesized using Superscript II reverse transcriptase (Invitrogen Life Technologies) and a specific primer complementary to the $3^{\prime}$ region of the gRNA to be quantified. cDNA was serially diluted prior to PCR to ensure that the reactions were in the linear range. PCR reactions contained $0.3 \mu \mathrm{M}$ of the appropriate $5^{\prime}$ and $3^{\prime}$ oligodeoxynucleotides and were performed for a total of 35 cycles. PCR products were separated on $3 \%$ agarose gels and stained with ethidium bromide (EtBr). Contrast on the images was inverted for figure preparation.

\section{Immunoprecipitation experiments}

Cross-linking of antibodies to Protein A-Sepharose was performed as described (Pelletier et al. 2001). Mitochondrial vesicles from $1 \times 10^{10}$ to $1 \times 10^{11}$ cells (EATRO 164) were lysed in $1 \mathrm{~mL}$ of lysis buffer as described (Hayman and Read 1999). One hundred micrograms of preimmune IgGs or anti-RBP16 cross-linked to Protein A-Sepharose were added to $300 \mu \mathrm{L}$ of extract along with $50 \mathrm{U}$ of RNasin (Promega) and the sample incubated for $4 \mathrm{~h}$ at $4^{\circ} \mathrm{C}$ with gentle rocking. Immune complexes were recovered by centrifugation at $10,000 \mathrm{~g}$ for $30 \mathrm{~s}$ and washed five times with $500 \mu \mathrm{L}$ of wash buffer (lysis buffer containing $0.1 \%$ Nonidet P-40). RNA was isolated from Protein A-Sepharose pellets and supernatants by incubation for $15 \mathrm{~min}$ at $37^{\circ} \mathrm{C}$ in wash buffer containing $0.5 \%$ SDS and $50 \mu \mathrm{g} / \mathrm{mL}$ proteinase $\mathrm{K}$. The reactions were extracted twice with phenol-chloroform and RNA precipitated with ethanol using glycogen as a carrier. gRNA was identified by labeling $5^{\prime}$ ends with guanylyl transferase (a generous gift from Dr. Edward Niles, State University of New York-Buffalo) in the presence of $\left[\alpha-{ }^{32} \mathrm{P}\right] \mathrm{GTP}$ (Perkin Elmer; $10 \mu \mathrm{Ci} / \mu \mathrm{L}, 800 \mathrm{Ci} / \mathrm{mmole}), 50 \mathrm{mM}$ Tris- $\mathrm{HCl}(\mathrm{pH}$ 8.0), $1.5 \mathrm{mM} \mathrm{MgCl}_{2}, 6 \mathrm{mM} \mathrm{KCl}, 2.5 \mathrm{mM} \mathrm{DTT}$, and $25 \mathrm{U}$ of
RNasin (Hayman and Read 1999). Labeled RNA was separated on a $7 \mathrm{M}$ urea/6\% polyacrylamide gel and visualized by autoradiography.

$\mathrm{gCYb}[558]$ and gCR6 [100] were detected in supernatants and pellets by Northern analysis. RNA isolated from the supernatants and pellets was electrophoresed on a $2.2 \mathrm{M}$ formaldehyde-3\% agarose gel at $100 \mathrm{~V}$ in $1 \times$ MOPS buffer. The RNA was then transferred to Nytran by capillary in $10 \times$ SSPE. gCYb [558]-3' and gCR6[100]-3' were ${ }^{32} \mathrm{P}$-labeled using Klenow in the presence of $\left[\alpha-{ }^{32} \mathrm{P}\right] \mathrm{dATP}$ (Perkin Elmer; $10 \mu \mathrm{Ci} / \mu \mathrm{L}, 800 \mathrm{Ci} / \mathrm{mmole}$ ) and used as probes. Prehybridization and hybridization were carried out at room temperature for 5 and $20 \mathrm{~h}$, respectively in $50 \%$ formamide, $5 \times$ SSPE, $1 \%$ sarkosyl, and $0.05 \mathrm{mg} / \mathrm{mL}$ salmon sperm DNA. Blots were washed twice for $10 \mathrm{~min}$ at room temperature, with a final wash at $37^{\circ} \mathrm{C}$ in $5 \times$ SSPE, $0.1 \%$ sarkosyl.

\section{ACKNOWLEDGMENTS}

We are grateful to Dr. Paul T. Englund for providing the pZJM vector and to Dr. Mark Drew for his advice on transfection. We thank Dr. George A.M. Cross for his gift of culture-adapted bloodstream form T. brucei strain 427 and procyclic form T. brucei strain 29-13, Dr. Noreen Williams for providing anti-PABI antibodies, and Dr. Edward G. Niles for providing guanylyltransferase. We also thank Dr. Mark Hayman for carrying out the Western blot analyses of total procyclic and bloodstream form parasite extracts. This work was supported by NIH grants GM53502 and AI47329 to L.K.R.

The publication costs of this article were defrayed in part by payment of page charges. This article must therefore be hereby marked "advertisement" in accordance with 18 USC section 1734 solely to indicate this fact.

Received October 15, 2002; accepted December 27, 2002.

\section{REFERENCES}

Aphasizhev, R., Sbicego, S., Peris, M., Jang, S.-H., Aphasizhev, I., Simpson, A.M., Rivlin, A., and Simpson, L. 2002. Trypanosome mitochondrial 3' terminal uridylyl transferase (TUTase): The key enzyme in U-insertion/deletion RNA editing. Cell 108: 637-648.

Bae, W., Xia, B., Inouye, M., and Severinov, K. 2000. Escherichia coli CspA-family RNA chaperones are transcription antiterminators. Proc. Natl. Acad. Sci. USA 97: 7784-7789.

Bedford, M.T., Frankel, A., Yaffe, M.B., Clarke, S., Leder, P., and Richard, S. 2000. Arginine methylation inhibits the binding of proline-rich ligands to Src Homology 3, but not WW, domains. J. Biol. Chem. 275: 16030-16036.

Bhat, G.J., Souza, A.E., Feagin, J.E., and Stuart, K. 1992. Transcriptspecific developmental regulation of polyadenylation in Trypanosoma brucei mitochondria. Mol. Biochem. Parasitol. 52: 231-240.

Blom, D., Burg, J.V., Breek, C.K., Speijer, D., Muijsers, A.O., and Benne, R. 2001. Cloning and characterization of two guide RNAbinding proteins from mitochondria of Crithidia fasciculata: gBP27, a novel protein, and gBP29, the orthologue of Trypanosoma brucei gBP21. Nucleic Acids Res. 29: 2950-2962.

Brun, R. and Schonenberg, M. 1979. Cultivation and in vitro cloning of procyclic culture forms of Trypanosoma brucei in a semi-defined medium. Acta Trop. 36: 289-292.

Chen, C.-Y., Gherzi, R., Andersen, J.S., Gaietta, G., Jürchott, K., Royer, H.-D., Mann, M., and Karin, M. 2000. Nucleolin and YB-1 are required for JNK-mediated interleukin-2 mRNA stabilization dur- 
ing T-cell activation. Genes \& Dev. 14: 1236-1248.

Costanzo, M.C. and Fox, TD. 1990. Control of mitochondrial gene expression in Saccharomyces cerevisiae. Annu. Rev. Genet. 24: 91113.

Drozdz, M., Palazzo, S.S., Salavati, R., O’Rear, J., Clayton, C., and Stuart, K. 2002. TbMP81 is required for RNA editing in Trypanosoma brucei. EMBO J. 21: 1791-1799.

Estévez, A.M. and Simpson, L. 1999. Uridine insertion/deletion RNA editing in trypanosome mitochondria: A review. Gene 240: 247260.

Evdokimova, V.M., Kovrigina, E.A., Nashchekin, D.V., Davydova, E.K., Hershey, J.W.B., and Ovchinnikov, L.P. 1998. The major core protein of messenger ribonucleoprotein particles (p50) promotes initiation of protein biosynthesis in vitro. J. Biol. Chem. 273: $3574-$ 3581.

Evdokimova, V., Ruzanov, P., Imataka, H., Raught, B., Svitkin, Y., Ovchinnikov, L.P., and Sonenberg, N. 2001. The major mRNAassociated protein YB- 1 is a potent $5^{\prime}$ cap-dependent mRNA stabilizer. EMBO J. 20: 5491-5502.

Feagin, J.E., Jasmer, D.P., and Stuart, K. 1985. Apocytochrome b and other mitochondrial DNA sequence are differentially expressed during the life cycle of Trypanosoma brucei. Nucleic Acids Res. 13: 4577-4595.

- 1987. Developmentally regulated addition of nucleotides within apocytochrome $b$ transcripts in Trypanosoma brucei. Cell 49: 337-345.

Grams, J., McManus, M.T., and Hajduk, S.L. 2000. Processing of polycistronic guide RNAs is associated with RNA editing complexes in Trypanosoma brucei. EMBO J. 19: 5525-5532.

Graumann, P.L. and Marahiel, M.A. 1998. A superfamily of proteins that contain the cold shock domain. Trends Biochem. Sci. 23: 286290.

Grosset, C., Chen, C.Y., Xu, N., Sonenberg, N., Jacquemin-Sablon, H., and Shyu, A.-B. 2000. A mechanism for translationally coupled mRNA turnover: Interaction between the poly(A) tail and a c-fos RNA coding determinant via a protein complex. Cell 103: 29-40.

Hayman, M.L. and Read, L.K. 1999. Trypanosoma brucei RBP16 is a mitochondrial Y-box family protein with guide RNA binding activity. J. Biol. Chem. 274: 12067-12074.

Hayman, M.L., Miller, M.M., Chandler, D.M., Goulah, C.C., and Read, L.K. 2001. The trypanosome homolog of human p32 interacts with RBP16 and stimulates its gRNA binding activity. Nucleic Acids Res. 29: 5216-5225.

Hirumi, H. and Hirumi, K. 1989. Continuous cultivation of Trypanosoma brucei blood stream forms in a medium containing a low concentration of serum protein without feeder cell layers. J. Parasitol. 75: 985-989.

Hotchkiss, T.L., Nerantzakis, G.E., Dills, S.C., Shang, L., and Read, L.K. 1999. Trypanosoma brucei poly(A) binding protein I cDNA cloning, expression, and binding to $5^{\prime}$ untranslated region sequence elements. Mol. Biochem. Parasitol. 98: 117-129.

Huang, C.E., Cruz-Reyes, J., Zhelonkina, A.G., O’Hearn, S., Wirtz, E., and Sollner-Webb, B. 2001. Roles for ligases in the RNA editing complex of Trypanosoma brucei: Band IV is needed for U-deletion and RNA repair. EMBO J. 20: 4694-4704.

Islas-Osuna, M.A., Ellis, T.P., Marnell, L.L., Mittelmeier, T.M., and Dieckmann, C.L. 2002. Cbp1 is required for translation of the mitochondrial cytochrome b mRNA of Saccharomyces cerevisiae. J. Biol. Chem. 277: 37987-37990.

Jasmer, D.P., Feagin, J.E., and Stuart, K. 1985. Diverse patterns of expression of the cytochrome $\mathrm{c}$ oxidase subunit I gene and unassigned reading frames 4 and 5 during the life cycle of Trypanosoma brucei. Mol. Cell. Biol. 5: 3041-3047.

Jiang, W., Hou, Y., and Inouye, M. 1997. CspA, the major cold-shock protein of Escherichia coli, is an RNA chaperone. J. Biol. Chem. 272: 196-202.

Köller, J., Müller, U.F., Schmid, B., Missel, A., Kruft, V., Stuart, K., and Göringer, H.U. 1997. Trypanosoma brucei gBP21. An arginine-rich mitochondrial protein that binds to guide RNA with high affinity.
J. Biol. Chem. 272: 3749-3757.

Koslowsky, D.J. and Yahampath, G. 1997. Mitochondrial mRNA 3' cleavage/polyadenylation and RNA editing in Trypanosoma brucei are independent events. Mol. Biochem. Parasitol. 90: 81-94.

Koslowsky, D.J., Riley, G.R., Feagin, J.E., and Stuart, K. 1992. Guide RNAs for transcripts with developmentally regulated RNA editing are present in both life cycle stages of Trypanosoma brucei. Mol. Cell. Biol. 12: 2043-2049.

Lambert, L., Müller, U.F., Souza, A.E., and Göringer, H.U. 1999. The involvement of gRNA-binding protein gBP21 in RNA editing-An in vitro and in vivo analysis. Nucleic Acids Res. 27: 1429-1436.

Leung, S.S. and Koslowsky, D.J. 1999. Mapping contacts between gRNA and mRNA in trypanosome RNA editing. Nucleic Acids Res. 27: 778-787.

Madison-Antenucci, S. and Hajduk, S.L. 2001. RNA editing-associated protein 1 is an RNA binding protein with specificity for preedited mRNA. Mol. Cell 7: 879-886.

Madison-Antenucci, S., Sabatini, R.S., Pollard, V.W., and Hajduk, S.L. 1998. Kinetoplastid RNA-editing associated protein 1 (REAP-1): A novel editing complex protein with repetitive domains. EMBO J. 17: 6368-6376.

Madison-Antenucci, S., Grams, J., and Hajduk, S.L. 2002. Editing machines: The complexities of trypanosome RNA editing. Cell 108: $435-438$.

Matsumoto, K. and Wolffe, A.P. 1998. Gene regulation by Y-box proteins: Coupling control of transcription and translation. Trends Cell. Biol. 8: 318-323.

Mertens, P.R., Harendza, S., Pollock, A.S., and Lovett, D.H. 1997. Glomerular mesangial cell-specific transactivation of matrix metalloproteinase 2 transcription is mediated by YB-1. J. Biol. Chem. 272: 22905-22912.

Michelotti, E.F., Harris, M.E., Adler, B., Torri, A.F., and Hajduk, S.L. 1992. Trypanosoma brucei mitochondrial ribosomal RNA synthesis, processing and developmentally regulated expression. Mol. Biochem. Parasitol. 54: 31-42.

Militello, K.T., Hayman, M.L., and Read, L.K. 2000. Transcriptional and post-transcriptional in organello labeling of Trypanosoma brucei mitochondrial RNA. Int. J. Parasitol. 30: 643-647.

Missel, A., Souza, A.E., Nörskau, G., and Göringer, H.U. 1997. Disruption of a gene encoding a novel mitochondrial DEAD-box protein in Trypanosoma brucei affects edited mRNAs. Mol. Cell. Biol. 17: 4895-4903.

Müller, U.F., Lambert, L., and Göringer, H.U. 2001. Annealing of RNA editing substrates facilitated by the guide RNA-binding protein gBP21. EMBO J. 20: 1394-1404.

Norman, J.T., Lindahl, G.E., Shakib, K., En-Nia, A., Yilmaz, E., and Mertens, P.R. 2001. The Y-box binding protein YB-1 suppresses collagen $\alpha 1$ (I) gene transcription via an evolutionarily conserved regulatory element in the proximal promoter. J. Biol. Chem. 276: $29880-29890$.

Panigrahi, A.K., Gygi, S., Ernst, N., Igo Jr., R.P., Palazzo, S.S., Schnaufer, A., Weston, D., Carmean, N., Salavati, R., Aebersold, R., et al. 2001. Association of two novel proteins TbMP52 and TbMP48 with the Trypanosoma brucei RNA editing complex. Mol. Cell. Biol. 21: 380-389.

Pelletier, M., Miller, M.M., and Read, L.K. 2000. RNA binding properties of the mitochondrial Y-box protein RBP16. Nucleic Acids Res. 28: 1266-1275.

Pelletier, M., Xu, Y., Wang, X., Zahariev, S., Pongor, S., Aletta, J.M., and Read, L.K. 2001. Arginine methylation of a mitochondrial guide RNA binding protein from Trypanosoma brucei. Mol. Biochem. Parasitol. 118: 49-59.

Pisarev, A.V., Skabkin, M.A., Thomas, A.A., Merrick, W.C., Ovchinnikov, L.P., and Shatsky, I.N. 2002. Positive and negative effects of the major mammalian messenger ribonucleoprotein p50 on binding of $40 \mathrm{~S}$ ribosomal subunits to the initiation codon of $\beta$-globin mRNA. J. Biol. Chem. 277: 15445-15451.

Pitula, J., Ruyechan, W.T., and Williams, N. 2002. Two novel RNA binding proteins from Trypanosoma brucei are associated with $5 \mathrm{~S}$ 
rRNA. Biochem. Biophys. Res. Comm. 290: 569-576.

Read, L.K., Myler, P.J., and Stuart, K. 1992. Extensive editing of both processed and preprocessed maxicircle CR6 transcripts in Trypanosoma brucei mitochondria. J. Biol. Chem. 267: 1123-1128.

Read, L.K., Stankey, K.A., Fish, W.R., Muthiani, A.M., and Stuart, K. 1994. Developmental regulation of RNA editing and polyadenylation in four life cycle stages of Trypanosoma congolense. Mol. Biochem. Parasitol. 68: 297-306.

Riley, G.R., Corell, R.A., and Stuart, K. 1995. Multiple guide RNAs for identical editing of Trypanosoma brucei apocytochrome $b$ mRNA have an unusual minicircle location and are developmentally regulated. J. Biol. Chem. 269: 6101-6108.

Rödel, G. 1997. Translational activator proteins required for cytochrome $b$ synthesis in Saccharomyces cerevisiae. Curr. Genet. 31: 375-379.

Rusché, L.N., Cruz-Reyes, J., Piller, K.J., and Sollner-Webb, B. 1997. Purification of a functional enzymatic editing complex from Trypanosoma brucei mitochondria. EMBO J. 16: 4069-4081.

Safak, M., Sadowska, B., Barrucco, R., and Khalili, K. 2002. Functional interaction between JC virus late regulatory agnoprotein and cellular Y-box binding transcription factor, YB-1. J. Virol. 76: 38283838.

Schnaufer, A., Panigrani, A.K., Panicucci, B., Igo Jr., R.P., Salavati, R., and Stuart, K.D. 2001. An RNA ligase essential for RNA editing and survival of the bloodstream form of Trypanosoma brucei. Science 291: 2159-2162.

Schmid, B., Riley, G.R., Stuart, K., and Göringer, H.U. 1995. The secondary structure of guide RNA molecules from Trypanosoma brucei. Nucleic Acids Res. 23: 3093-3102.

Seiwert, S.D. 1995. The ins and outs of editing RNA in kinetoplastids. Parasitol. Today 11: 362-368.

Shapiro, T.A. and Englund, P.T. 1995. The structure and replication of kinetoplast DNA. Annu. Rev. Microbiol. 49: 117-143.

Skabkin, M.A., Evdokimova, V., Thomas, A.A.M., and Ovchinnikov, L.P. 2001. The major messenger ribonucleoprotein particle protein p50 (YB-1) promotes nucleic acid strand annealing. J. Biol. Chem. 276: 44841-44847.

Sommerville, J. and Ladomery, M. 1996. Masking of mRNA by Y-box proteins. FASEB J. 10: 435-443.

Stickeler, E., Fraser, S.D., Honig, A., Chen, A.L., Berget, S.M., and Cooper, T.A. 2001. The RNA binding protein YB-1 binds A/C-rich exon enhancers and stimulates splicing of the CD44 alternative exon v4. EMBO J. 20: 3821-3830.

Stuart, K. and Panigrahi, A.K. 2002. RNA editing: Complexity and complications. Mol. Microbiol. 45: 591-596.

Stuart, K., Panigrahi, A.K., Schnaufer, A., Drozdz, M., Clayton, C., and Salavati, R. 2002. Composition of the editing complex of Trypanosoma brucei. Phil. Trans. R. Soc. Lond. 357: 71-79.

Van den Hoff, M.J.B., Moorman, A.F.M., and Lamers, W.H. 1992. Electroporation in intracellular buffer increases cell survival. $\mathrm{Nucl}$. Acids. Res. 20: 2902.

Vanhamme, L., Perez-Morga, D., Marchal, C., Speijer, D., Lambert, L., Geuskens, M., Alexandre, S., Ismaïli, N., Göringer, U., Benne, R., et al. 1998. Trypanosoma brucei TBRGG1, a mitochondrial oligo(U)-binding protein that co-localizes with an in vitro RNA editing activity. J. Biol. Chem. 273: 21825-21833.

Wang, Z., Morris, J.C., Drew, M.E., and Englund, P.T. 2000. Inhibition of Trypanosoma brucei gene expression by RNA interference using an integratable vector with opposing T7 promoters. J. Biol. Chem. 275: 174-179.

Weber, E.R. and Dieckmann, C.L. 1990. Identification of the CBP1 polypeptide in mitochondrial extracts from Saccharomyces cerevisiae. J. Biol. Chem. 265: 1594-1600.

Wirtz, E., Leal, S., Ochatt, C., and Cross, G. 1999. A tightly regulated inducible expression system for conditional gene knock-outs and dominant-negative genetics in Trypanosoma brucei. Mol. Biochem. Parasitol. 99: 89-101.

Zhu, W., Mustelin, T., and David, M. 2002. Arginine methylation of STAT1 regulates its dephosphorylation by T cell protein tyrosine phosphatase. J. Biol. Chem. 277: 35787-35790. 

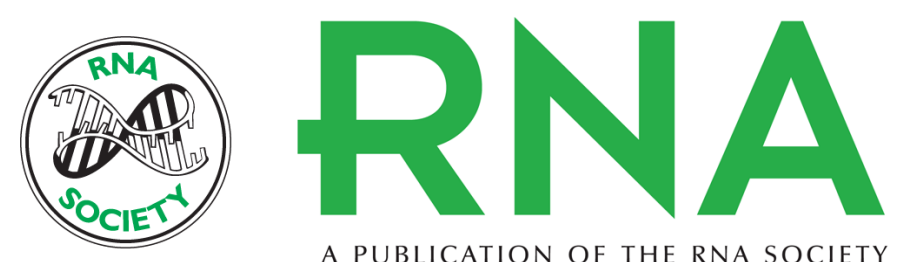

A PUBLICATION OF THE RNA SOCIETY

\title{
RBP16 is a multifunctional gene regulatory protein involved in editing and stabilization of specific mitochondrial mRNAs in Trypanosoma brucei
}

\author{
MICHEL PELLETIER and LAURIE K. READ
}

RNA 2003 9: 457-468

References This article cites 66 articles, 30 of which can be accessed free at: http://rnajournal.cshlp.org/content/9/4/457.full.html\#ref-list-1

\section{License}

Email Alerting

Receive free email alerts when new articles cite this article - sign up in the box at the Service top right corner of the article or click here.

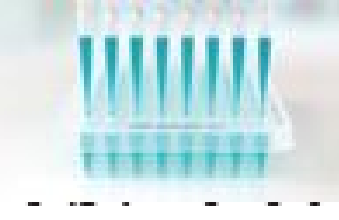

